\title{
CAMBRIDGE
}

\section{MAGNA CARTA, RELIGION \\ and the RULE OF LAW}

EDITED BY

Robin Griffith-Jones and Mark Hill QC, Editors

\$99.99: Hardback: 9781107100190431 pp.

\$39.99: Paperback: 9781107494367

Archbishop Stephen Langton hoped with Magna Carta to realise an Old Testament, covenantal kingship in England. At the Charter's 800th anniversary, distinguished jurists, theologians and historians from five faith-traditions and three continents ask how Magna Carta's biblical foundations have mattered and still matter now. A Lord Chief Justice, a Chief Rabbi, a Grand Mufti of Egypt, specialists in eight centuries of law, scholars and advocates committed to the rule of law and to the place of religion in public life all come together in this testimony to Magna Carta's iconic power. We follow the Charter's story in the religious life of the UK, America and now Continental Europe, and reflections on religio-legal traditions far from the Common Law enrich the story. Magna Carta, Religion and the Rule of Law invites all religions to ask what contribution they themselves should make to the rule of law in today's secular, democratic polities.

\section{Robin Griffith-Jones and Mark Hill QC have assembled a magisterial} line-up of thinkers to tease out critical issues around law and religion. Magna Carta, Religion and the Rule of Law is an important book bringing substantial intellectual resources to bear on a key subject for our time; it deserves thoughtful, questioning reading. 99

JUSTIN WELBY, Archbishop of Canterbury

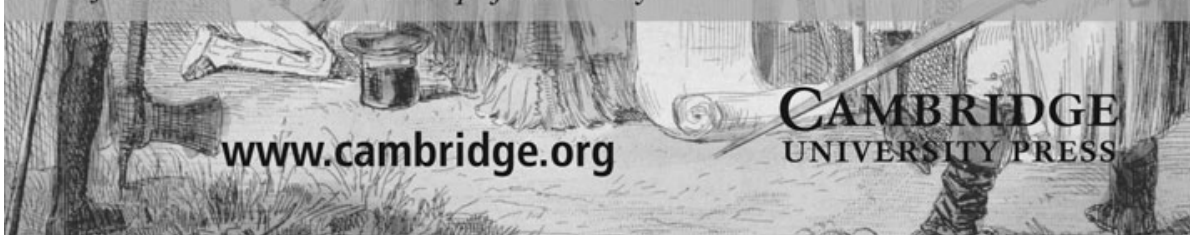




\section{Ecclesiastical Law Journal}

The Ecclesiastical Law Journal is published by the Ecclesiastical Law Society. The views expressed in any article, comment, review or other publications in this Journal do not necessarily accord with those of the Editor, the Editorial Board, or the Society as a whole.

\section{Submission of Articles and Comment}

The Ecclesiastical Law Journal covers all aspects of ecclesiastical law, with a particular emphasis on the legal regulation of the Church of England and the worldwide Anglican Communion. Its range of coverage also includes comparative studies of the laws of other faiths and of the interface between law and religion in United Kingdom jurisprudence and worldwide. General policy is developed by the Editor in collaboration with the Editorial Board.

The Ecclesiastical Law Journal is peer reviewed and operates an anonymous double blind refereeing process using members of the Editorial Board together with others expert in the particular field concerned. Authors should therefore take care not to identify themselves within the text of the manuscript which they submit. Articles should generally be between 5,000 and 7,000 words and Comment pieces should not exceed 2,000 words. All submissions should be made to the Editor.

General inquiries and articles submitted for publication should be addressed to Dr Will Adam, St Paul's Vicarage, Church Hill, London, N21 1JA; Tel o2o 8886 3545; E-mail:ecclj@me.com Authors are reminded that they must follow the format set out in 'House Style', copies of which may be downloaded from http://journals.cambridge.org/elj.

\section{Book Reviews}

Books for review may be sent to: JDC Harte, Book Review Editor, Ecclesiastical Law Journal, 8 Westminster Gate, Winchester, $\mathrm{SO}_{2} 2 \mathrm{LN}$; Tel o1962 859555; E-mail: harte.david@gmail.com Case Notes

Matters relating to case notes should be addressed to: The Worshipful Ruth Arlow, Ecclesiastical Law Journal, 5 Temple Chambers, Temple Street, Swindon SN1 1SQ; Tel 01793 539899; Fax o845 259 3242; E-mail: rutharlow@hotmail.com

Parliamentary Report and Synod Reports Matters relating to synod reports and parliamentary activities should be addressed to: Frank Cranmer, 145 Marsham Court, Marsham Street, London Sw1P 4LB; Tel 07774981988 ;

E-mail: fcranmer@dunelm.org.uk

\section{Ecclesiastical Law Society}

Inquiries with regard to membership of the Ecclesiastical Law Society, should be addressed to: Andrew Male, Administrator, Ecclesiastical Law Society, c/o 1 The Sanctuary, Westminster, London SW1P 3JT; Tel O20 7222 5381. E-mail: admin@ ecclawsoc.org.uk; www.ecclawsoc.org.uk

The Ecclesiastical Law Journal is included in the Cambridge Journals Online journals service which can be found at http://journals.cambridge.org/elj. For further information on other Press journals access http://cambridge.org/journals.

ISSN $0956-618 \mathrm{X}$

\section{Ecclesiastical Law Society London Lectures 2016}

Wednesday 27 January

Chancellor Charles Mynors

'The Faculty Jurisdiction Rules 2015: all change (again)?'

Wednesday 16 March

Francesca Quint and Alastair Hunter

'Winding up/leaving a religious community'

Wednesday 22 June

Andreas Hendriksen Aarflot

'Relations between church and state: the Norwegian experience'

October (date to be advised)

Chancellor Timothy Briden

'Confirmation of episcopal elections' 


\section{Contents}

I EDITORIAL

Will Adam

ARTICLES

2 Polity and Polemics: The Function of Ecclesiastical Polity in

Theology and Practice

Paul Avis

14 The Constitutional Justification of Religion

Rafael Domingo

36 The Problem of the Non-justiciability of Religious Defamations Peter Smith

COMMENT

53 Parliament and the 1662 Book of Common Prayer

Colin Buchanan

62 Religious Courts in the Jurisprudence of the European Court of Human Rights

Michat Rynkowski

NOTABLE ECCLESIASTICAL LAWYERS: $X$

67 John de Burgh (fl 1370-1398)

Richard Helmholz

73 PARLIAMENTARY REPORT

78 CONFERENCE REPORTS

83 SYNOD REPORTS

102 BOOK REVIEWS

122 CASE NOTES

Cambridge Journals Online For further information about this journal please go to the journal's web site at: journals.cambridge.org/elj

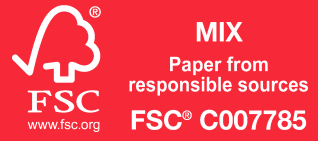

